\title{
Annual wood formation of tropical pioneer species related to stem diameters
}

\author{
Kang Han Wang ${ }^{*}$ and Mohd Zaki Hamzah
}

\begin{abstract}
Annual wood increment and cambial activity in Macaranga gigantea and Endospermum diadenum growing in tropical rainforest were monitored to examine their relationship with stem sizes and climatic factors. The monitoring period was done from March 2013 to February 2014. Wood blocks containing phloem, cambium and outer sapwood were collected monthly from the main trunk of selected trees. Results showed that M. gigantea with smaller stem diameter showed higher annual diameter increment $(16.63 \pm 7.2 \mathrm{~mm})$ than those with larger stem diameters $(3.30 \pm 0.1 \mathrm{~mm})$ The total amount of wood formed in E. diadenum with larger stem diameter $(9.17 \pm 0.3 \mathrm{~mm})$ was higher than the trees with smaller stem size $(3.33 \pm 0.3 \mathrm{~mm})$. The rhythm of cambial activity were found different among tree species and stem diameters within the same species. M. gigantea with smaller stem diameter had longer active cambial growth period and produced higher number of cell layers than trees with larger stem diameter. In contrast, E. diadenum with larger stem diameter showed longer active growth period and higher number of cell layers than trees with smaller stem diameter. This study showed no significant correlation between mean number of cambial and enlarging cell layers with monthly total rainfall, monthly mean relative humidity, vapor pressure deficit and day length. Significant negative correlations were detected between maximum temperature and number of cambial and enlarging cell layers in M. gigantea with smaller stem size. For E. diadenum with smaller stem size, monthly mean temperature had significant negative correlation with the number of cambial cell layer. This study concluded that the intra-annual wood formation patterns of this two pioneer species are species specific and stem sizes specific.
\end{abstract}

Keywords: Cambial activity, Dendrometer, E. diadenum, M. gigantea, Stem diameter, Tropical rainforest

\section{Introduction}

Forest disturbance are happening in many parts of the world and the restoration of secondary forest is of great concern [1]. In the process of forest recovery, the growth of tropical pioneer species which are well known as fast growing species and enhancing the growth of latesuccessional species, is particularly important for forest rehabilitation [2]. In South East Asia, the widespread of tropical pioneer species such as Macaranga gigantea and Endospermum diadenum provides high ecological relevance to the restoration of secondary forests $[3,4]$. Knowledge governing growth of these species and its relationship to climatic conditions is, thus, crucial in the practice of forest management and silvicultural system in

*Correspondence: wkanghan@gmail.com

Faculty of Forestry, Universiti Putra Malaysia, 43400 Serdang, Selangor, Malaysia this region. Nevertheless, the effect of climatic variability to the growth and survival of these species is generally not well known.

Radial growth of tree is determined by its cambial activity. The study of cambial activity and annual wood growth provides valuable information on forest growth dynamics $[5,6]$ and how its growth is affected by climatic factors (temperature, rainfall, vapor pressure deficit, relative humidity, day length) [7, 8]. Studies on seasonal cambial activity have been conducted in temperate regions $[9,10]$, and tropical regions $[11,12]$. In temperate forests, seasonal climate leads to clear annual periodicity of cambial activity. Cambial activity of tropical trees was reported related to the distribution of precipitation. Marcati et al. [13, 14] reported that the active period of cambium in some semi-deciduous seasonal forest species as Cedrela fissilis and Schizolobium parahyba coincided with rainy season, and the dormant period is in the dry 
season. Other study demonstrated climatic factors other than rainfall. Schippers [15] found that maximum temperature had a strong negative effect on the stem growth of tropical trees. Marcati et al. [16] reported that maximum temperature was correlated with cambial activity of tropical trees. Most of the previous studies focused on the influence of climatic factors on cambial dynamics, and relatively few studies have focused on the effects of tree stem diameter on the cambial dynamics of tropical trees. Investigation of tree growth from different sizes is crucial to understand the timing and duration of xylogenesis within species of different stem diameter as well as to understand phenology and accurate assess climatetree growth relationship.

The extent to which the relationships between tree radial growth and climatic factors depend on tree diameter remain uncertain. Recent eco-physiological studies suggest that functional processes and xylem phenology are closely related to tree sizes [17-23] and they undergo changes as trees increase in size [24-27]. De Luis et al. [28] reported that tree growth sensitivity to climate is greater between sizes than between species. Thus, there is a need to disentangle the effects of size on wood formation to better understand the drivers of tree growth and variation in wood formation within species. For tropical species, studies providing a comprehensive view of tropical tree growth sensitivity to stem sizes are currently unavailable.

To better understand the effects of tree stem diameters on radial tree growth, we studied the wood increment and cambial phenology (number of cell layers) of $M$. gigantea and $E$. diadenum of different stem diameters and their responses to climatic factors. Cambial activity in $M$. gigantea and E. diadenum of different stem sizes growing in tropical rain forest has not been previously reported and are, thus, still missing. We monitor the intra-annual dynamics of wood formation in the two pioneer species during the 2013 and 2014 growing season. Trees were selected based on their stem diameters to disentangle the effects of these two factors on xylem formation. We hypothesis that the dynamics of xylem growth is species- and size dependent.

\section{Materials and methods}

\section{Study site and climatic conditions}

This study was conducted from March 2013 to February 2014 on trees growing at tropical rainforest of West Peninsular Malaysia. The forest is a lowland dipterocarp rainforest located in Ayer Hitam Forest Reserve, Selangor $\left(2^{\circ} 56^{\prime} \mathrm{N}-101^{\circ} 46^{\prime} \mathrm{E}\right)$. It is a secondary rainforest which has yet to reach its full rehabilitation [29]. The site receives monthly rainfall of more than $100 \mathrm{~mm}$ for the major months of a year (Fig. 1). During the experimental period, the highest total monthly rainfall $(434.2 \mathrm{~mm})$ was recorded in December 2013, while the lowest monthly rainfall $(18.1 \mathrm{~mm})$ was recorded in February 2014 . The minimum temperature ranged from 24.2 to $26.6{ }^{\circ} \mathrm{C}$, mean monthly temperature ranged from 25.9 to $28.1{ }^{\circ} \mathrm{C}$, and maximum temperature ranged from 27.6 to $29.4{ }^{\circ} \mathrm{C}$. The highest relative humidity $(80.2 \%)$ was recorded in March 2013, while the lowest relative humidity (64.7\%) was recorded in February 2014. Climatic data of the study site were collected from the Department of Meteorological Malaysia. Day length of the study site ranged from 11.65 to $12.17 \mathrm{~h}$, and these data were collected from timeanddate.com [30] as the Department of Meteorological Malaysia does not provide this data.

\section{Tree selection}

Macaranga gigantea and Endospermum diadenum from the family of Euphobiaceae were selected for this study. Twelve sampled trees with straight-boled stems and no trunk deformity were chosen from the site. Two-diameter class was selected with one diameter from 11 to $17 \mathrm{~cm}$, while the other represented larger diameter of $26-30 \mathrm{~cm}$. Six trees were selected for each diameter range. Two diameter ranges were selected based on their availability at the study site. The exact age of the sampled trees was unknown. As evergreen trees, $M$. gigantea and $E$. diadenum bear leaves all year around. For M. gigantea, flower buds were observed at the end of wet months in August 2013. Flowering occurred at the beginning of wet months in September, while fruiting occurred during the wet months from October to December 2013. Fruit ripening was observed in December when the total monthly rainfall was the highest throughout the experimental period. For E. diadenum, flowering occurs twice a year between February and April, and August to October. Mature fruits were present $2-3$ months after flowering. Phenological observation provides indication for tree climate-growth relationship; nevertheless, during the experimental period, all samples trees were evergreen with continuous leaf fall and flushing.

\section{Dendrometer measurement}

An aluminum band dendrometer [31] was installed on each trunk of the sampled trees at breast height. The dendrometer was then left on for almost 2 months after installation to ensure that the aluminum band fits well to the tree trunk. Dendrometer data were measured monthly under the natural condition to provide the total diameter increment for the sampled trees. The diameter growth of trees was measured with the accuracy of $0.01 \mathrm{~cm}$. The mean monthly values and standard deviations in Fig. 2 were the results from the mean value of 

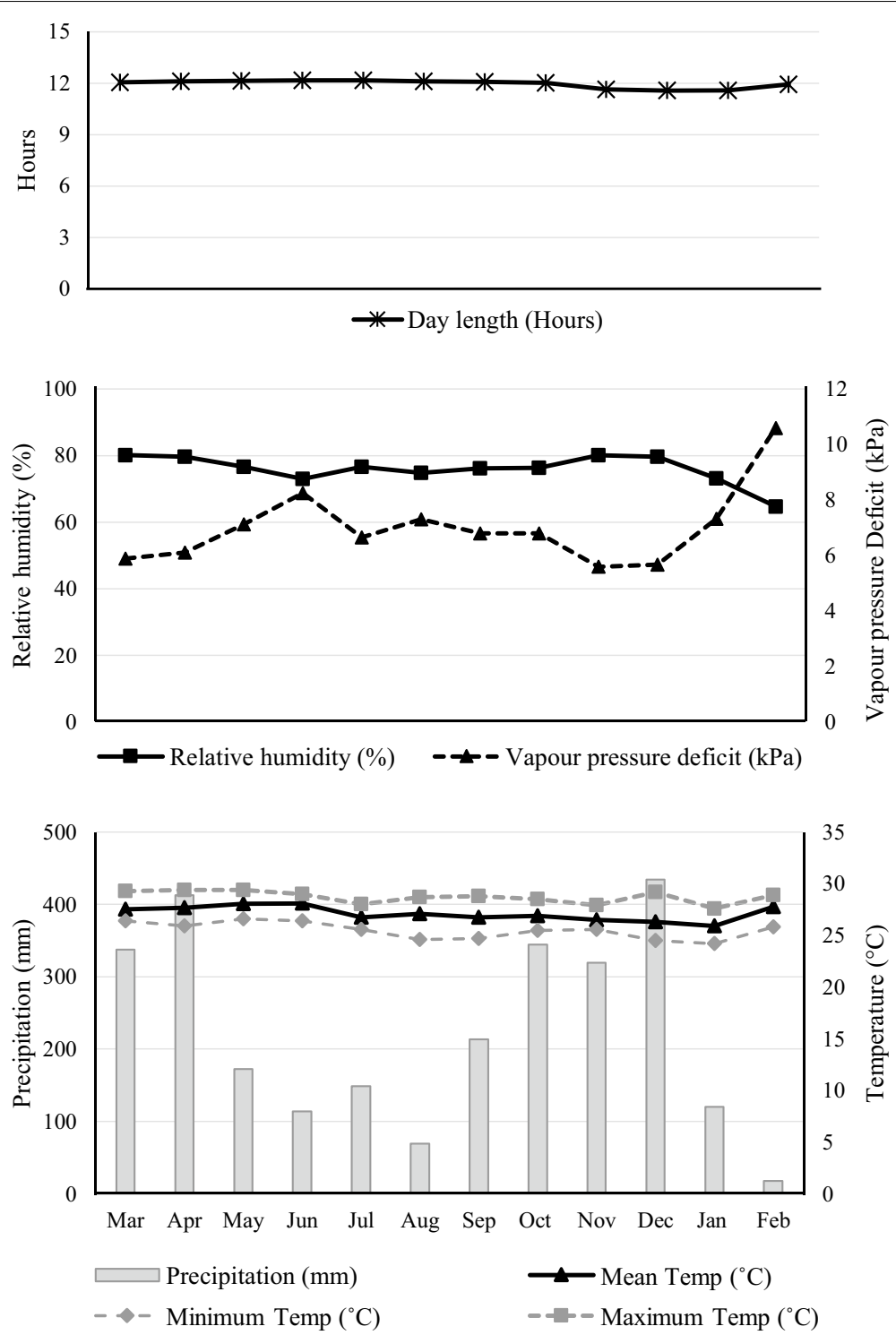

Fig. 1 Climatic conditions of study site during the experimental period from March 2013 to February 2014

each tree from different species and stem diameter classes within species.

\section{Wood sample collection and preparation}

Cambial activities of 3 smaller and 3 larger diameter trees from each species were selected to study cambial dynamics. All selected trees were heathy and with upright stems. Wood blocks $(2 \times 2 \times 2 \mathrm{~cm})$ including inner phloem, cambial tissues and outer xylem were extracted monthly from the main trunks of the living trees using chisel, hammer and knife. Sampling was carefully done to avoid compression of cambial tissue and separation of bark and wood. Samples that were extracted from the living trees were immediately fixed with $3 \%$ glutaraldehyde solution for disinfection and preservation. To avoid the effects of wounding, a safe distance $(8 \mathrm{~cm})$ was considered between each samples extracted position. This was to ensure that the new samples would not contain wound wood which result from the cambium's response to the previous samplings.

In the laboratory, the specimens were thoroughly washed with distilled water before their dimensions were reduced to $2 \times 2 \times 2 \mathrm{~mm}$. The specimens were then dehydrated in a graded series of ethanol at increasing concentrations (30, 50, 70, 95 and 99.8\%). The specimens were then embedded in the epoxy resin. Cross sections with a 


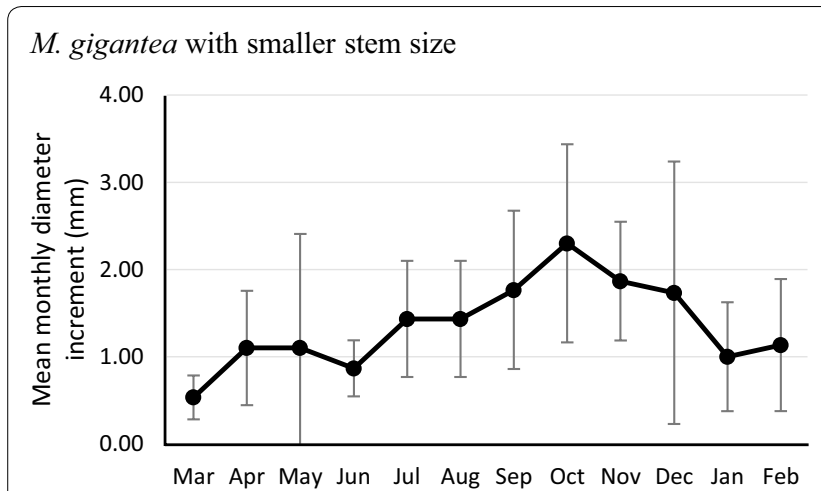

M. gigantea with larger stem size

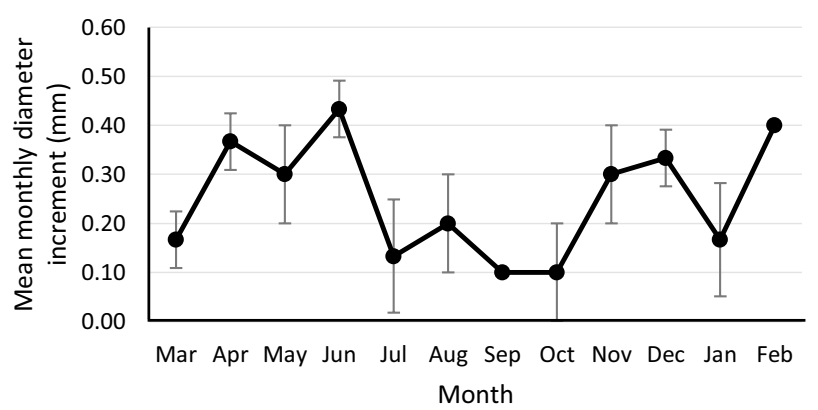

E. diadenum with smaller stem size

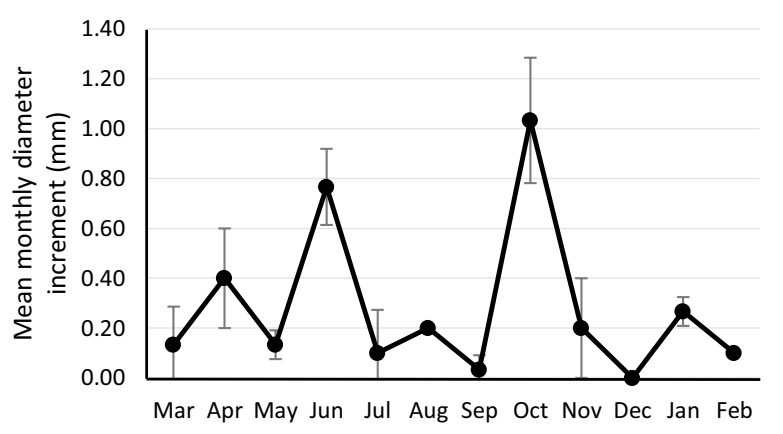

E. diadenum with larger stem size

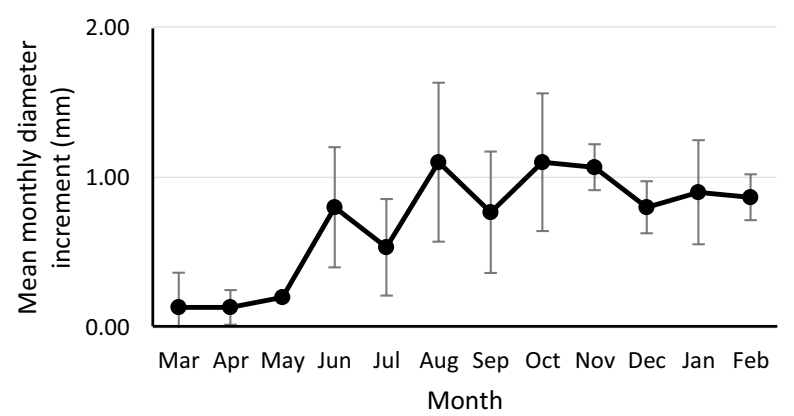

Fig. 2 Monthly mean diameter increment of sample trees measured by dendrometer

thickness of 16-20 $\mu \mathrm{m}$ were cut from the epoxy embedding blocks using a Leica SM 2000R sliding microtome. Wood sections were stained with the Periodic AcidSchiff's (PAS) reaction [32] and mounted with dibutyl phthalate xylene (DPX) mounting medium for the preparation of permanent microscope slides.

\section{Data analysis}

Anatomical characteristics of cambial activity were observed under a Leica LEITZ DMRB light microscope under bright field and polarized light. The anatomical characteristics of cambium were determined by counting the number of cambial and enlarging cell layers. The criteria described by Rossi et al. [33] were used to determine the number of cell layers. The cambial cell in this study refers to the group of radially flattened cells with thin cell wall between phloem and xylem. Enlarging cells refer to the cells that are next to the cambial cells, which show larger dimension than the cambial cell in cross section and presented thin cell walls that were not birefringent under polarized light. After enlarging cells, secondary wall formation starts to develop and the boundary between them can be distinguished under the polarized light microscope as secondary wall formation shows bright light in cross section view under polarized light.
Cambial dynamics was the result of fluctuations in the number of cambial and enlarging cell layers. A greater number of cell layers indicate higher cambial activities. The number of cambial and enlarging cell layers was averaged from 30 cell row counts from each sample tree. The mean values and standard deviations in Table 1 were calculated from the mean value of tree from different stem diameters. High average number of cambial and enlarging cell layers indicated active cambium, while less average number of cambial and enlarging cell layers indicated less active cambium. Peak cambial activity indicated the maximum mean number in cambial cells and enlarging cells. The number of cell layers was judged based on tree stem diameter as those trees produced different amount of cell layers.

Spearman's Rank Correlation Coefficient was used to evaluate the relationship between climatic factors and the number of cell layer in the cambial and enlarging cells for each species as they are discrete variables. Correlation analyses were applied for a better understanding of the general relationships between diameter growth dynamics and tree size, as well as between cambial dynamics and changes in climatic factors, which were then used to determine the climatic factors that accounts for most of the variation in tree growth. 
Table 1 Spearman rank correlation coeffcients between tree monthly mean diameter increment and climatic factors

\begin{tabular}{llccc}
\hline Climatic factors & \multicolumn{2}{l}{ Macaranga gigantea } & & \multicolumn{2}{c}{ Endospermum diadenum } \\
\cline { 2 - 3 } & Smaller stem & Larger stem & & Smaller stem \\
\hline Total rainfall $(\mathrm{mm})$ & 0.288 & -0.108 & -0.071 & Larger stem \\
Minimum temperature $\left({ }^{\circ} \mathrm{C}\right)$ & -0.488 & 0.455 & 0.102 & -0.317 \\
Mean temperature $\left({ }^{\circ} \mathrm{C}\right)$ & -0.467 & 0.518 & 0.214 & $-0.577^{\mathrm{a}}$ \\
Maximum temperature $\left({ }^{\circ} \mathrm{C}\right)$ & -0.432 & 0.508 & -0.216 & -0.349 \\
Mean relative humidity $(\%)$ & 0.123 & -0.108 & -0.250 & $-0.722^{\mathrm{b}}$ \\
Mean vapor pressure deficit $(\mathrm{hPa})$ & -0.351 & 0.173 & 0.218 & -0.399 \\
Day length (hour) & -0.309 & 0.00 & 0.175 & -0.217 \\
\hline
\end{tabular}

a Correlation is significant at the 0.05 level

b Correlation is significant at the 0.01 level

\section{Results}

\section{Tree diameter growth pattern and annual diameter} increment

Figure 2 shows the mean monthly diameter increment of sample trees during the monitoring year. For M. gigantea, trees with smaller stem diameters showed increasing growth rate from March to April, and decreasing growth rate on the onset of the dry months in May. These trees began to show increasing growth increment during the middle of the dry months in July until the onset of the wet months in October before showing decreasing growth increment during the middle of the wet months in November until the end of the monitoring period. $M$. gigantea with larger stem size showed decreasing growth increment during the onset of the dry months before showing an increased growth increment in June. The growth increment decreased once again in the middle of the dry months in July until the onset of wet month in October. Trees showed an increasing growth increment in months with high rainfalls, from October to December. Their growth increment decreased drastically during the onset of the dry month in January before it increased again in February. Both groups of trees with different stem sizes had different growth characteristics during the wet and dry months. Tree diameter increment for trees with larger stem size was found to increase in wet months, and decrease in dry months. Trees with smaller stem sizes, however, showed increasing growth increment during the middle of dry months and decreasing growth increment during wet months. Figures 3 and 4 show M. gigantea having different stem sizes exhibited different growth behaviors at the site with similar growing conditions.

For $E$. diadenum, trees with smaller stem sizes showed increasing growth increment from March to April before showing decreasing growth increment at the onset of dry month in May. The growth increment of those trees, however, increased drastically in June before decreasing drastically on the following months until the end of dry months. The growth increment of those trees increased in October. Nevertheless, the growth increment decreased once again from November to March, with slight increment in January. Nonetheless, trees with larger stem sizes did not show a clear growth diameter growth pattern. Peak diameter growth was found in the middle of dry month (August) and the onset of wet months (October). Decreasing growth increment was found in July, September (dry months) and December (wet months). The result also showed that $E$. diadenum with different stem sizes showed different growth behaviors at the site with similar growing conditions.

The correlations between tree monthly diameter increment and climatic factors are summarized in Table 1. No significant correlation was found between monthly diameter growth and climatic factors for $M$. gigantea and $E$. diadenum with smaller stem diameter. E. diadenum with larger stem diameter showed significant negative correlation with mean temperature and maximum temperature. The total of wood increment in M. gigantea was found to be different in trees with different stem diameters. Trees with smaller stem diameter showed higher increment growth $(16.63 \pm 7.2 \mathrm{~mm})$ in stem circumference than those with larger stem diameters $(3.30 \pm 0.1 \mathrm{~mm})$. Meanwhile, the total amount of wood formed in E. diadenum with larger stem diameter $(9.17 \pm 0.3 \mathrm{~mm})$ was higher than the trees with smaller stem size $(3.33 \pm 0.3 \mathrm{~mm})$. The growth of $E$. diadenum was noticed to increase when it reached larger stem size.

\section{Duration of cell production and cell differentiation}

The duration of cell production and cell differentiation was found different between M. gigantea and E. diadenum, and stem diameters within species (Table 2). For $M$. gigantea, trees with smaller stem diameter exhibited 


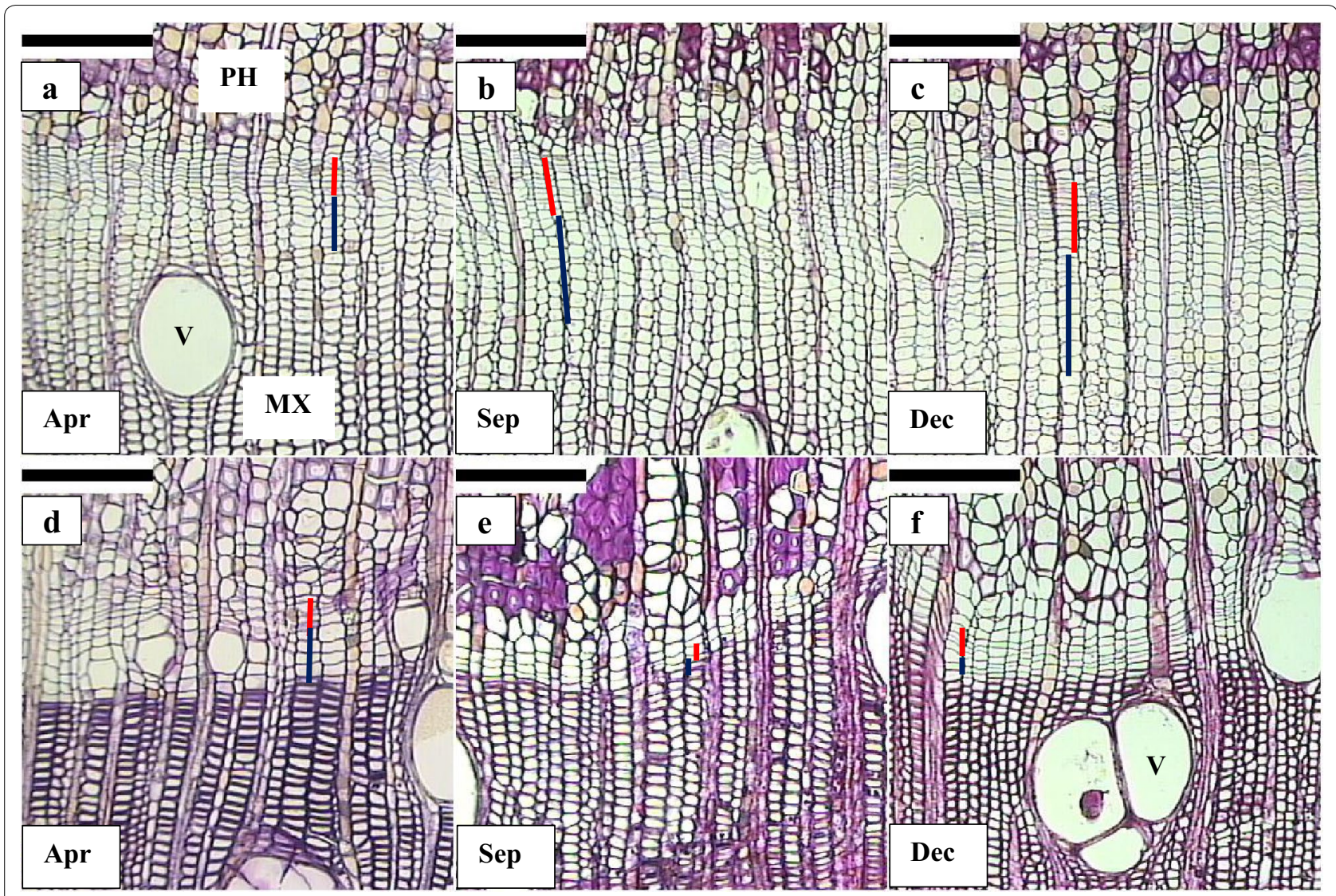

Fig. 3 Cross-sectional view of cambium with adjacent xylem and phloem in M. gigantea with smaller stem diameter (a-c) and larger stem diameter (d-f) during the study period. PH: Phloem; Red bar: Cambial cells; Blue bar: Enlarging cells; MX: Mature xylem; V: Vessel. Scale bars: 200 um

a significant longer cell production and cell enlargement period compared to trees with larger stem diameter during the study period. In addition, trees with smaller stem diameters produced higher number of cambial and enlarging cell layers than trees with larger stem diameter. For M. gigantea with smaller stem diameter, 8-9 cambial cell and 5-8 enlarging cell layers were recorded from March to June and in October. Relative active cambium was recorded from July to September and from December to February, with an average of 10-12 cambial cell layers and an average of 6-13 enlarging cell layers. Peak cambial activity was found in November with 12 cambial cell layers and 16 enlarging cell layers. For $M$. gigantea with larger stem diameter, an average of 4-6 cambial cell layers and an average of 3-4 enlarging cell layers were recorded from March to August, in October and February. Inactive cambial was found in September and December with an average of 2-3 cambial cell layers and an average of 2 enlarging cell layers. In November, cambium showed relatively active with 8 cambial cell and 5 enlarging cell layers.
Peak cambial activity was found in January with 9 cambial cell layers and 6 enlarging cell layers.

For E. diadenum, trees with larger stem diameters generally produced higher number of cambial and enlarging cell layers than trees with smaller stem diameter. For $E$. diadenum with smaller stem diameter, 4-5 cambial cell and 1-3 enlarging cell layers were recorded from March to April, in June, from September to October and in February. The cambial cell layers increased to six layers in May, December and January to six layers, while enlarging cell layer increased to 3-4 layers. Active cambium was found from July to August with an average of 7 cambial cell layers and an average of 4-5 enlarging cell layers. Peak cambial activity was found in November when the maximum number of cambial and enlarging cell layers was 8 and 5, respectively. For E. diadenum with larger stem diameter, 3-6 cambial and 1-3 enlarging cell layers were detected from March to April, in June, August, October and December. Relatively active cambium was showed in May, September, November, and from January to February with 7-10 cambial and 6-9 enlarging cell 


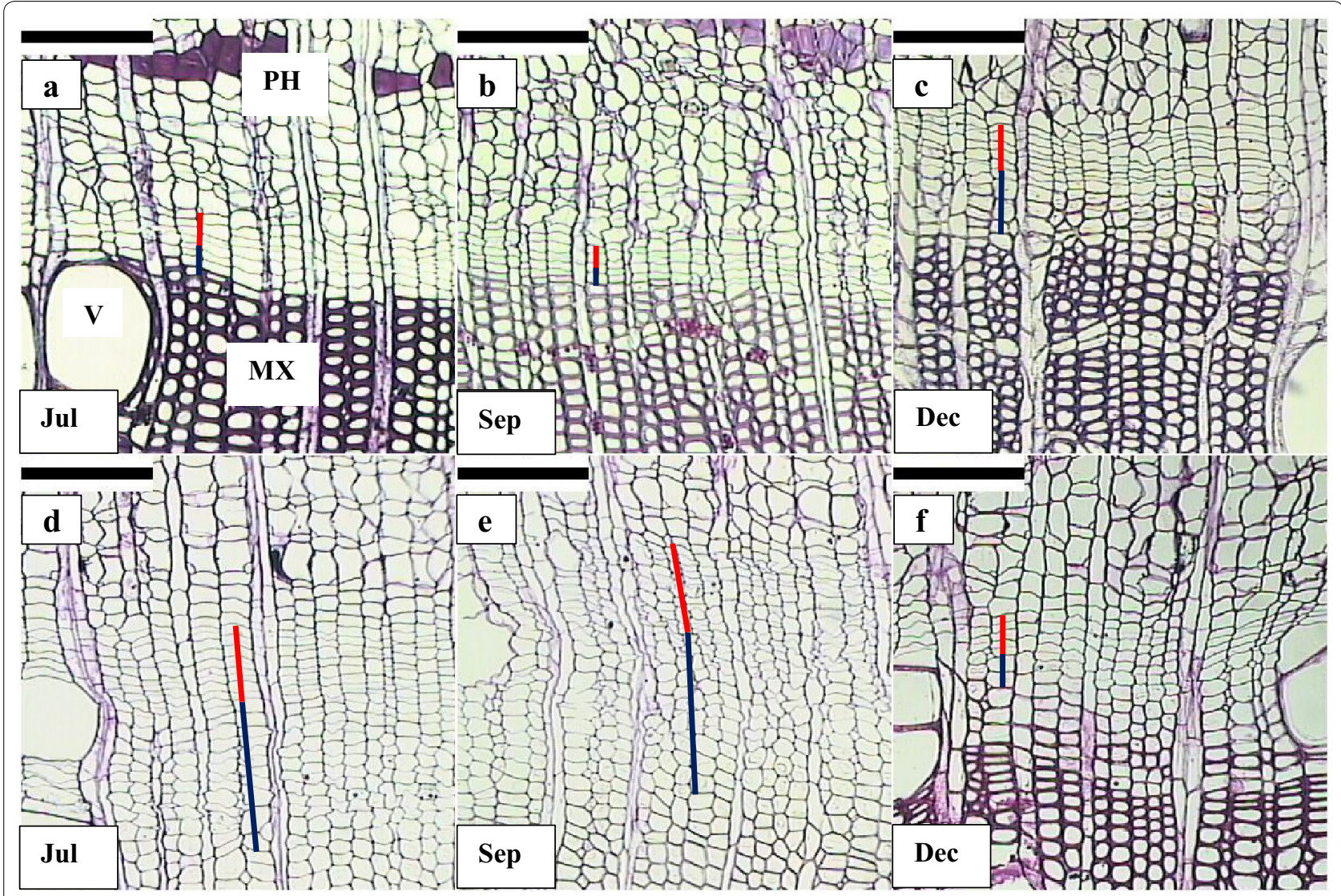

Fig. 4 Cross-sectional view of cambium with adjacent xylem and phloem in E. diadenum with smaller stem diameter (a-c) and larger stem diameter (d-f) during the study period. PH: Phloem; Red bar: Cambial cell; Blue bar: Enlarging zone cell; MX: Mature xylem; V: Vessel. Scale bars: $200 \mu \mathrm{m}$

Table 2 Mean number of cell layers in M. gigantea and E. diadenum during experimental period

\begin{tabular}{|c|c|c|c|c|c|c|c|c|}
\hline \multirow[t]{3}{*}{ Months } & \multicolumn{4}{|c|}{ Macaranga gigantea } & \multicolumn{4}{|c|}{ Endospermum diadenum } \\
\hline & \multicolumn{2}{|c|}{ Smaller stem } & \multicolumn{2}{|c|}{ Larger stem } & \multicolumn{2}{|c|}{ Smaller stem } & \multicolumn{2}{|c|}{ Larger stem } \\
\hline & $\mathrm{CC}$ & EC & $\mathrm{CC}$ & $\mathrm{EC}$ & $\mathrm{CC}$ & $\mathrm{EC}$ & $\mathrm{CC}$ & EC \\
\hline March & $8 \pm 0.58$ & $7 \pm 1.53$ & $5 \pm 2.94$ & $3 \pm 1.50$ & $5 \pm 1.29$ & $1 \pm 0.50$ & $5 \pm 1.00$ & $1 \pm 0.58$ \\
\hline April & $9 \pm 1.53$ & $5 \pm 0.58$ & $5 \pm 1.89$ & $4 \pm 0.96$ & $4 \pm 1.26$ & $3 \pm 1.29$ & $4 \pm 1.15$ & $2 \pm 0.58$ \\
\hline May & $9 \pm 1.15$ & $6 \pm 1.73$ & $6 \pm 4.99$ & $3 \pm 2.06$ & $6 \pm 1.29$ & $4 \pm 2.31$ & $8 \pm 0.58$ & $6 \pm 1.15$ \\
\hline June & $9 \pm 1.53$ & $6 \pm 1.73$ & $4 \pm 1.26$ & $3 \pm 1.41$ & $4 \pm 0.82$ & $2 \pm 1.15$ & $4 \pm 1.00$ & $1 \pm 0.58$ \\
\hline July & $12 \pm 2.08$ & $11 \pm 2.31$ & $4 \pm 1.29$ & $3 \pm 1.50$ & $7 \pm 4.65$ & $5 \pm 4.27$ & $11 \pm 1.53$ & $10 \pm 1.53$ \\
\hline August & $12 \pm 3.06$ & $13 \pm 4.51$ & $6 \pm 4.08$ & $4 \pm 3.20$ & $7 \pm 4.08$ & $4 \pm 2.63$ & $5 \pm 1.00$ & $2 \pm 0.58$ \\
\hline September & $11 \pm 4.16$ & $12 \pm 4.51$ & $2 \pm 0.96$ & $2 \pm 0.82$ & $5 \pm 2.16$ & $3 \pm 2.16$ & $9 \pm 1.15$ & $9 \pm 1.53$ \\
\hline October & $9 \pm 4.62$ & $8 \pm 4.51$ & $6 \pm 1.50$ & $4 \pm 2.63$ & $5 \pm 3.56$ & $3 \pm 1.50$ & $6 \pm 1.15$ & $3 \pm 0.58$ \\
\hline November & $12 \pm 6.43$ & $16 \pm 7.09$ & $8 \pm 1.29$ & $5 \pm 2.63$ & $8 \pm 1.29$ & $5 \pm 1.91$ & $7 \pm 2.31$ & $6 \pm 1.00$ \\
\hline December & $10 \pm 8.08$ & $10 \pm 7.94$ & $3 \pm 1.29$ & $2 \pm 0.58$ & $6 \pm 0.82$ & $3 \pm 1.29$ & $3 \pm 1.00$ & $3 \pm 1.15$ \\
\hline January & $11 \pm 3.79$ & $8 \pm 2.08$ & $9 \pm 2.38$ & $6 \pm 1.29$ & $6 \pm 3.86$ & $4 \pm 1.91$ & $10 \pm 0.58$ & $7 \pm 1.15$ \\
\hline February & $11 \pm 4.58$ & $6 \pm 3.00$ & $4 \pm 1.41$ & $3 \pm 0.58$ & $4 \pm 0.96$ & $2 \pm 1.26$ & $8 \pm 2.31$ & $7 \pm 1.15$ \\
\hline
\end{tabular}

CC: Mean number of cambial cell layers

EC: Mean number of enlarging cell layers

Itailc numbers indicate months of active cambial activities 
layers. Peak cambial activity was found in July when the maximum number of cambial and enlarging cell layers was 11 and 10 , respectively.

This study shows that in studies where comparison of the growth process across individual trees and species of interest is done, the stem size of trees must be taken into consideration for predicting tropical rainforest tree growth. In general, the sampled trees did not show any clear annual radial growth trend. This is different from the tropical tree growth pattern recorded from tropical seasonal forests with distinct dry and wet seasons, where rainfall is always considered as the main factor influencing tree growth. Additionally, it is worth to consider species-specific responses among tropical rainforest trees to similar environmental conditions for future studies as the studied species showed different growth characteristics and pattern throughout the monitoring year.

Relationship between cambial activity and climatic factors The correlations between the number of mean cell layers and climatic factors are summarized in Table 3. For $M$. gigantea with smaller stem size, a significantly negative correlation was found between the number of cambial cell layers with monthly maximum temperature, and between enlarging cell with monthly minimum, mean and maximum temperature. No significant correlation was found between numbers of mean cell layers with any climatic factors for both $M$. gigantea and E. diadenum with larger stem diameter. For E. diadenum with smaller stem size, a significant negative correlation was detected between number of cambial cell layers and monthly mean temperature. For both species, trees with smaller stem diameter generally showed more sensitive to climatic factors than trees with larger stem diameter.

\section{Discussion}

\section{Dendrometer measurement}

Macaranga gigantea with smaller stem diameter had relatively higher stem growth increment than those trees with larger stem diameters. Cambial study showed that trees with smaller diameter showed continuous cambial activity throughout the year, and thus have longer active growing period. The lower growth increment of trees with larger stem diameter was believed due to the aging process. Kohyama et al. [34] studied the relationship between tree size and growth rate, and reported that tree diameter growth rate decreased when the diameter of tree increased, and negative correlation was found between growth rate and tree size. Li et al. [17] and Rossi et al. [23] reported that young trees have longer growing season than old trees. Nevertheless, the growth increment in E. diadenum did not show the same phenomenon. The wood increment in E. diadenum with larger stem diameter was higher than those trees with smaller stem diameter. These results showed that not all tropical pioneer species have higher circumference growth rate during their juvenile stage.

Monthly diameter increment of all sample trees did not show any significant relationship with climatic factors such as rainfall, relative humidity, vapor pressure deficit and day length. The results of dendrometer measurement were similar to the cambial analysis which numbers of cambial and enlarging cell layer of all sample tree generally did not show any significant correlation with those climatic factors. Growth of the two evergreen species suggested that these species are less dependent on rainfall. Nevertheless, dendrometer and cambial analysis showed that the growth of both pioneer trees is negatively significantly correlated with temperature. Current study

Table 3 Spearman rank correlation coefficients between number of mean cell layers and climatic factors

\begin{tabular}{|c|c|c|c|c|c|c|c|c|}
\hline \multirow[t]{3}{*}{ Trees } & \multicolumn{4}{|c|}{ Macaranga gigantea } & \multicolumn{4}{|c|}{ Endospermum diadenum } \\
\hline & \multicolumn{2}{|c|}{ Smaller stem } & \multicolumn{2}{|c|}{ Larger stem } & \multicolumn{2}{|c|}{ Smaller stem } & \multicolumn{2}{|c|}{ Larger stem } \\
\hline & $\mathrm{CC}$ & $\mathrm{EC}$ & $\mathrm{CC}$ & $\mathrm{EC}$ & $\mathrm{CC}$ & EC & $\mathrm{CC}$ & EC \\
\hline Total rainfall (mm) & -0.433 & -0.007 & -0.085 & -0.113 & -0.011 & -0.076 & -0.429 & -0.233 \\
\hline Minimum temperature $\left({ }^{\circ} \mathrm{C}\right)$ & -0.556 & $-0.634^{\mathrm{a}}$ & -0.062 & -0.176 & -0.408 & -0.338 & -0.148 & -0.345 \\
\hline Mean temperature $\left({ }^{\circ} \mathrm{C}\right)$ & -0.520 & $-0.695^{\mathrm{a}}$ & -0.160 & -0.209 & $-0.619^{a}$ & -0.515 & -0.285 & -0.455 \\
\hline Maximum temperature $\left({ }^{\circ} \mathrm{C}\right)$ & $-0.713^{\mathrm{a}}$ & $-0.675^{\mathrm{a}}$ & -0.375 & -0.502 & -0.531 & -0.553 & -0.560 & -0.505 \\
\hline Mean relative humidity (\%) & -0.215 & 0.180 & 0.078 & -0.048 & 0.350 & 0.150 & -0.276 & -0.217 \\
\hline Mean vapor pressure deficit (hPa) & 0.047 & -0.346 & -0.004 & 0.026 & -0.387 & -0.216 & 0.278 & 0.120 \\
\hline Day length (Hour) & -0.112 & -0.236 & -0.185 & -0.183 & -0.136 & 0.032 & 0.039 & -0.169 \\
\hline
\end{tabular}

CC: Mean number of cambial cell layers

EC: Mean number of enlarging cell layers

a Correlation is significant at the 0.05 level

b Correlation is significant at the 0.01 level 
suggested that temperature is an important climatic factor to consider in determining the growth of $M$. gigantea and E. diadenum growing in tropical rainforest. Rahman et al. [35] reported Chukrasia tabularis growing in Bangladesh showed a significant negative correlation between tree growth with mean and maximum temperatures. Vlam et al. [36] documented that the monthly minimum- and maximum temperature is significantly negatively associated with tree growth in western Thailand.

\section{Vascular cambium activities}

The rhythm of cambial activity of the two pioneer species examined were not synchronized during the examined growth period. $M$. gigantea with smaller stem diameter showed continuous cambial activity throughout the entire study period, while $M$. gigantea with larger stem diameter and $E$. diadenum with different stem diameter showed periods of active and less active period. This study revealed that $M$. gigantea and $E$. diadenum generated different diameter growth patterns and adaptive strategies to similar growing conditions. Sass et al. [37] reported that Shorea leprosula growing in Peninsular Malaysia under the weak seasonal climate site shows continuous cambial activity. The growth of those trees showed no relation to the seasonality of precipitation and phenology. Similar results were reported by Rajput and Rao [38] and Evert [39] that trees show continuous cambial activity throughout the entire year or during major months of a growing season. Krepkowski et al. [40] reported that deciduous broad-leaved trees of Celtis africana are sensitive to climatic factors, while evergreen conifer and some broad-leaved trees species are relatively less sensitive to climatic variation. Their study showed that the responses of cambium to climatic variation are dependent on tree species.

M. gigantea with smaller stem diameter possessed higher number of cambial and enlarging cell layers than those of tree with smaller stem diameter throughout the study period. However, E. diadenum with larger stem size generally showed higher number of cambial and enlarging cell layers that those trees with smaller stem size. Hence, $M$. gigantea with smaller stem size and $E$. diadenum with larger stem size in this study were believed to have higher growth increment than those species with different stem diameter. Rathgeber et al. [41] reported that cambial activities of Abies alba are related to tree stem diameter. Their results show that the timing, duration and rate of xylem production of silver fir change according to the stem diameter. Nabeshima et al. [42] reported that the size dependency of tree diameter growth results in different interactive effect on tree growth to growing conditions. Pumijumnong and Wanyaphet [43] revealed that the response of cambial dynamics in Pinus merkusii and Pinus kesiya to growing climatic factors is dependent upon the age of the trees. Tree physiological processes such as water and nutrient supplies demand, photosynthesis rates and hydraulic resistance are related to tree size as trees respond differently to growing conditions which result in different growth pattern [23]. Hence, the rate and period of cell production in different stem diameter are an essential component of tree growth which should be taken into consideration when studying intraannual dynamics of wood formation.

Relationship between cambial activity and climatic factors Peak cambial activity of $M$. gigantea and E. diadenum with smaller stem size was detected in the middle of wet months (November). Active cambial activity of those trees was recorded in dry months (July-September). Peak cambial activity of $M$. gigantea and $E$. diadenum with larger stem diameter was found in the beginning and the middle of dry months, respectively. This study is in contrast to those studies reported previously, where precipitation plays a significant role in influencing cambial activity of tropical trees. The relationship between tropical tree growth and precipitation is generally positive in tropical forest sites. [44-49]. Nevertheless, the current study showed that climatic factors such as rainfall, relative humidity, vapor pressure deficit and day length do not play significant roles in determining the cambial activity of both pioneer species as no significant correlations were found between number of cambial and enlarging cell layers and climatic factors. These results were similar to the study conducted by Marcati et al. [16] which reported that the cambial activity of trees growing at Cerrado sensu stricto was not simultaneous with the onset and end of rainy season, but corresponded to the core of the rainy season (when a minimum of $66 \%$ of the annual precipitation has been reached). The soil of the site is a combination of alluvium-colluvium soil derived from metamorphic stones with sandy clay loam soil texture $[29,50]$. This soil texture with small particles has high water-holding capacity to store water which can prolong the cambial activity. The correlation analysis of the current study showed that the numbers of cambial and enlarging cell layers in M. gigantea with smaller stem size and the number of cambial cell layer of $E$. diadenum showed significant negative correlation with temperature. Similar result was reported for trees growing in Bangladesh moist tropical forests [51]. This negative relationship between tree growth and temperature may due to reduced rate of photosynthesis and high evapotranspiration rate as the result of higher temperature [52]. Meir et al. [53] found that an air temperature increase of $10{ }^{\circ} \mathrm{C}$ will cause a higher respiration rates in trees growing in tropical rainforest. In this study, temperature for 
the study site was quite constant along sampling period. Nevertheless, the monthly minimum, mean and maximum temperature seem to affect cambial activity differently depending on stem size within species. Rossi et al. [23] and Rozas et al. [54] reported climate sensitivity of radial growth changes with cambial age. Martinez-Vilalta et al. [18] and Vanderklein et al. [22] documented that many functional process in trees are depended on tree age and sizes. Hitherto, little such information is available for trees growing in tropical rain forest. Effort should be made to investigate the effect of tree size to climategrowth relationships of tropical trees owing to it may weaken the climatic signal of the chronology.

$M$. gigantea and E. diadenum with different stem diameter within species showed different wood annual increment and cambial dynamics. Results of the current study were from a specific area, species and year. Therefore, these results cannot be generalized to other tropical pioneer species growing in different tropical regions. Nevertheless, this study revealed the existence of the effect of diameter stem size on climate-tree growth relationship in a tropical rainforest. This study suggests that future studies should consider the effect of tree stem diameter when interpreting tropical tree growth.

\section{Conclusion}

Our study provided insights into intra-annual stem diameter growth of $M$. gigantea and $E$. diadenum trees with smaller and larger stem diameters growing under natural conditions in tropical rainforest. Dendrometer data were used to determine total annual growth increment of samples trees during the study growing period. $M$. gigantea trees with smaller diameter had higher diameter growth increment than trees with larger stem diameter. In contrast, E. diadenum trees with larger stem diameter showed higher diameter growth increment than trees with smaller stem diameter. Total annual diameter increment from dendrometer measurements showed that the diameter growth rate of these two pioneer species was size dependent. The cambial responses of these two species growing at the same site demonstrated species specific and size dependent. M. gigantea trees with smaller stem diameter had longer active cambial growth period and produced higher number of cell layers than trees with larger stem diameter. In contrast, E. diadenum trees with larger stem diameter showed longer active growth period and higher number of cell layers than trees with smaller stem diameter. These results showed that cell production rate is an important factor to consider when examining diameter growth of trees. This study generally showed no significant correlation between number of cell layers and climatic factors such as rainfall, vapor pressure deficit, relative humidity and day length. Significant negative correlations were detected between maximum temperature and number of cambial and enlarging cell layers in M. gigantea with smaller stem size. For $E$. diadenum with smaller stem size, monthly mean temperature had significant negative correlation with the number of cambial cell layer. The differences of annual diameter growth increment and cambial dynamics between trees with smaller and larger stem diameters within a species and different species provided important information on the growth variation of tropical pioneer tree species. These variations found in this study should be further studied as the growth response of tropical pioneer species to climatic factors is of interest to forest recovery effort and enhancement of tropical silviculture system in this region.

\section{Abbreviations}

M. gigantea: Macaranga gigantea; E. diadenum: Endospermum diadenum; PAS: Periodic Acid-Schiff's; CC: mean number of cambial cell layers; EC: mean number of enlarging cell layers; $\mathrm{PH}$ : phloem; MX: mature xylem; $\mathrm{V}$ : vessel.

\section{Acknowledgements}

This research was carried out within the project funded by the Research University Grant Scheme, RUGS 9386500. We would like to thank all who have contributed to the success of this project, with special thanks to the forest rangers of Ayer Hitam Forest Reserve for their help in collecting samples.

\section{Authors' contributions}

$\mathrm{KHW}$ and $\mathrm{MZH}$ generated the study design. KHW conducted the field and laboratory works, analyzed and interpreted data. MZH supervised throughout the project period. KHW wrote the manuscript and MZH contributed to the final manuscript. MZH approved the final version of the manuscript to be submitted. All authors read and approved the final manuscript.

\section{Funding}

This research was carried out within the project funded by the Research University Grant Scheme, RUGS 9386500.

\section{Availability of data and materials}

The datasets used and/or analyzed during the current study are available from the corresponding author on reasonable request.

\section{Consent for publication}

All authors approve of the publication on your journal if this paper has been received.

\section{Competing interests}

The authors declare that they have no competing interests.

Received: 10 December 2018 Accepted: 30 May 2019

Published online: 06 June 2019

References

1. Makana JR, Thomas SC (2008) Impacts of selective logging and agricultural cleaning on forest structure, floristic composition and diversity, and timber tree regeneration in the Ituri Forest, Democratic Republic of Congo. Biodivers Conserv 15:1375-1397

2. Hooper E, Legendre P, Condit R (2005) Barriers to forest regeneration of deforested and abandoned land in Panama. J Appl Ecol 42:1165-1174

3. Karyati Ipor IB, Jusoh I, Wasli ME (2017) The diameter increment of selected tree species in a secondary tropical forest in Sarawak, Malaysia. Biodiversitas 18:304-311 
4. Widiyatno Budiadi, Suryanto P, Rinarno YDBM, Prianto SD, Hendro Y, Hosaka T, Numata S (2017) Recovery of vegetation structure, soil nutrients and late-succession species after shifting cultivation in central Kalimantan, Indonesia. JTFS 29:151-162

5. Jacoby GC (1989) Overview of tree-ring analysis in tropical regions. IAWA Bull NS 10:99-108

6. Worbes M (1995) How to measure growth dynamics in tropical trees-a review. IAWA J 16:337-351

7. Gričar J, Prislan P, Gryc V, Vavrčík H, de Luis M, Čufar K (2014) Plastic and locally adapted phenology in cambial seasonality and production of xylem and phloem cells in Picea abies from temperate environments. Tree Physiol 34:869-881

8. Begum S, Nakaba S, Oribe Y, Kubo T, Funada R (2010) Cambial activity to rising temparatures by natural condition and artificial heating from late winter to early spring in the evergreen conifer Cryptomeria japonica. Trees 24:43-52

9. Antonova GF, Stasova W (1993) Effects of environmental factors on wood formation in Scots pine stems. Trees 7:214-219

10. Rensing KH, Samuel AL (2004) Cellular changes associated with rest and quiescence in winter-dormant vascular cambium of Pinus contorta (Pinaceae). Trees 18:373-380

11. Aref IM, Khan PR, Al-Mefarrej H, Al-Shahrani T, Ismail A, labal M (2014) Cambial periodicity and wood production in Acacia ehrenbergiana Hayne growing on dry sites of Saudi Arabia. J Environ Biol 35:301-310

12. Oliveira JM, Santarosa E, Pillar VD, Roig FA (2009) Seasonal cambium activity in the subtropical rain forest tree Araucaria angustifolia. Trees 23:107-115

13. Marcati CR, Angyalossy V, Evert RF (2006) Seasonal variation in wood formation of Cedrela fissilis (Meliaceae). IAWA J 27:199-211

14. Marcati CR, Milanez CRD, Machado SR (2008) Seasonal development of secondary xylem and phloem in Schizolobium parahyba (Vell.) Blake (Leguminosae: caesalpinioidead). Trees 22:3-12

15. Schippers P, Sterck F, Vlam M, Zuidema PA (2015) Tree growth variation in the tropical forest: understanding effects of temperature, rainfall and $\mathrm{CO}_{2}$. Glob Chang Biol 21:2749-2761

16. Marcati CR, Machado SR, Podadera DS, de Lara NOT, Bosio F, Wiedenhoeft AC (2016) Cambial activity in dry and rainy season on branches from woody species growing in Brazilian Cerrado. Flora 223:1-10

17. Li X, Liang E, Gričar J, Prislan P, Rossi S, Čufar K (2013) Age dependence of xylogenesis and its climatic sensitivity in Smith fir on the southeastern Tibetan Plateau. Tree Physiol 33:48-56

18. Martinez-Vilalta J, Vanderklein D, Mencuccini M (2007) Tree height and age-related decline in growth in Scots pine (Pinus sylvestris L.). Oecologia 150:529-544

19. McDowell NG, Licata J, Bond BJ (2005) Environmental sensitivity of gas exchange in different-sized trees. Oecologia 145:9-20

20. Midgley JJ (2003) Is bigger better in plants? The hydraulic costs of increasing size in trees. Trends Ecol Evol 18:5-6

21. Nabeshima E, Hiura T (2007) Size-dependency in hydraulic and photosynthetic properties of three Acer species having different maximum size. Ecol Res 23:281-288

22. Vanderklein D, Martinez-Vilalta J, Lee S, Mencuccini M (2007) Plant size, not age, regulates growth and gas exchange in grafted Scots pine trees. Tree Phys 27:71-79

23. Rossi S, Deslauriers A, Anfodillo T, Carrer M (2008) Age-dependent xylogenesis in timberline conifers. New Phytol 177:199-208

24. Mencuccini M, Martinez-Vilalta J, Vanderklein D, Hamid HA, Korakaki E, Lee S, Michiels B (2005) Size-mediated ageing reduces vigour in trees. Ecol Lett 8:1183-1190

25. Munne-Bosch S (2007) Aging in perennials. Crit Rev Plant Sci 26:123-138

26. Peñuelas J (2005) Plant physiology —a big issue for trees. Nature 437:965-966

27. Wang KH, Hamzah MZ (2018) Different cambial activites in response to climatic factors of three Malaysian rainforest Shorea species with different stem diameters. Trees 32:1519-1530

28. De Luis M, Novak K, Čufar K, Raventós J (2009) Size mediated climategrowth relationships in Pinus halepensis and Pinus pinea. Trees 23:1065-1073
29. Faridah Hanum I (1999) Plant diversity and conservation value of Ayer Hitam Forest, Selangor, Peninsular Malaysia. Pertanika J Trop Agric Sci 22:73-83

30. Time and Date (1995) Stavanger, Norway. https://www.timeanddat e.com. Accessed 25 Feb 2019

31. Liming FG (1957) Homemade dendrometers. J For 55:575-577

32. McManus JFA (1948) Histological and histochemical uses of periodic acid. Stain Technol 23:99-108

33. Rossi S, Deslauriers A, Anfodillo T (2006) Assessment of cambial activity and xylogenesis by microsampling tree species: an example at the alpine timberline. IAWA J 27:383-394

34. Kohyama T, Suzuki E, Partomihardjo T, Yamada T, Kubo T (2003) Tree species differentiation in growth, recruitment and allometry in relation to maximum height in a Bornean mixed dipterocarp forest. J Ecol 91:797-806

35. Rahman M, Islam M, Bräuning A (2017) Local and regional climatic signals recorded in tree-rings of Chukrasia tabularis in Bangladesh. Dendrochronologia 45:1-11

36. Vlam M, Baker PJ, Bunyavejchewin S, Zuidema PA (2014) Temperature and rainfall strongly drive temporal growth variation in Asian tropical forest trees. Oecologia 174:1449-1461

37. Sass U, Killman W, Eckstein D (1995) Wood formation in two species of Dipterocarpaceae in Peninsular Malaysia. IAWA J 16:371-384

38. Rajput KS, Rao KS (2000) Cambial activity and development of wood in Acacia nilotica (L.) Del. growing in different forests of Gujarat state. Flora 195:165-171

39. Evert RF (2006) Esau's Plant Anatomy: Meristems, Cells, and Tissues of the Plant Body: Their Structure, Function, and Development, 3rd edn. Wiley, Hoboken

40. Krepkowski J, Bräuning A, Gebrekirstos A, Strobl S (2011) Cambial growth dynamics and climatic control of different tree life forms in tropical mountain forest in Ethiopia. Trees 25:59-70

41. Rathgeber CBK, Rossi S, Bontemps JD (2011) Cambial activity related to tree size in a mature silver-fir plantation. Ann Bot 108:429-438

42. Nabeshima E, Kubo T, Hiura T (2010) Variation in tree diameter growth in response to the weather conditions and tree size in deciduous broad-leaved trees. For Ecol Manage 259:1055-1066

43. Pumijumnong $N$, Wanyaphet $T$ (2006) Seasonal cambial activity and tree-ring formation of Pinus merkusii and Pinus kesiya in Northern Thailand in dependence on climate. For Ecol Manage 226:279-289

44. Pumijumnong N, Buajan S (2012) Seasonal cambial activity of five tropical tree species in central Thailand. Trees 27:409-417

45. Chowdhury MQ, DeRidder M, Beeckman H (2016) Climatic signals in tree rings of heritiera fomes buch,- - Ham. in the Sundarbans, Bangladesh. PLoS ONE 11(2):e0149788

46. Couralet C, Sterck FJ, Sass-Klaassen U, Van Acker J, Beeckman H (2010) Species-specific growth responses to climate variations in understorey trees of a central African rain forest. Biotropica 42:503-511

47. Rajput KS, Rao KS, Patil UG (2005) Cambial anatomy, development and structural changes in the wood of teak (Tectona grandis L.f.) associated with inset defoliation. J Sustain For 20:51-63

48. Rao KS, Rajput KS (1999) Seasonal behavior of vascular cambial on teak (Tectona grandis) growth in moist deciduous and dry deciduous forest. IAWA J 20:85-93

49. Volland-Voigt F, Bräuning A, Ganzhi O, Peters T, Maza H (2011) Radial stem variations of Tabebuia chrysantha (Bignoniaceae) in different tropical forest ecosystems of southern Ecuador. Trees 25:39-48

50. Awang Noor AG, Norini H, Khamurudin MN, Ahmad Ainuddin N, Thorsen BJ (2007) Economic valuation of timber resources in Ayer Hitam Forest Reserve, Puchong, Selangor. Pertanika J Trop Agric Sci 30:83-96

51. Rahman M, Islam M, Bräuning A (2018) Tree radial growth is projected to decline in South Asian moist forest trees under climate change. Global Planet Change 170:106-119

52. Galbraith D, Levy PE, Sitch S, Huntingford C, Cox P, William M, Meir P (2010) Multiple mechanisms of Amazonia forest biomass losses in three dynamic global vegetation models under climate change. New Phytol 187:647-665 
53. Meir P, Metcalfe DB, Costa ACL, Fisher RA (2008) The rate of assimilated carbon during drought: impacts on respiration in Amazon rainforests. Philos Trans R Soc Lond B Biol Sci 363:1849-1855

54. Rozas V, Desoto L, Olano JM (2009) Sex-specific, age-dependent sensitivity of tree-ring growth to climate in the dioecious tree Juniperus thurifera. New Phytol 182:687-697

\section{Publisher's Note}

Springer Nature remains neutral with regard to jurisdictional claims in published maps and institutional affiliations.

\section{Submit your manuscript to a SpringerOpen ${ }^{\circ}$ journal and benefit from:}

- Convenient online submission

- Rigorous peer review

- Open access: articles freely available online

- High visibility within the field

- Retaining the copyright to your article

Submit your next manuscript at $\boldsymbol{\nabla}$ springeropen.com 